\title{
RITUXIMAB DELAYS WOUND HEALING AND DECREASES WHITE BLOOD CELL COUNT IN MALE MICE
}

\author{
SELMAN M SELMAN ${ }^{1}$, MAJID K BASHARA ${ }^{1}$, AHMED RAJI ${ }^{2}$, OUDAY H KADHUM ${ }^{3}$ \\ ${ }^{1}$ Department of Pharmacology, College of Medicine, University of Babylon, Babylon, Iraq. ${ }^{2}$ Department of Pathology, College of Medicine, \\ University of Babylon, Babylon, Iraq. ${ }^{3}$ Department of Internal Medicine, College of Medicine, University of Babylon, Babylon, Iraq. \\ Email: dr_selmanmohammed14@ubabylon.edu.iq \\ Received: 30 September 2016, Revised and Accepted: 28 January 2017
}

ABSTRACT

Objective: The aims of this research are to evaluate the effect of rituximab on wound healing, some hematological parameters, histological changes in wound healing, and histopathological changes in some organs in male mice.

Methods: Totally, 15 adult male mice (25-30 g) were enrolled in this study. Animals were kept in the animal house College of Medicine/University of Babylon, and the temperature was controlled on $25^{\circ} \mathrm{C}$ and $14 \mathrm{hrs}$ light and $10 \mathrm{hrs}$ dark cycles. The animals were provided with standard diet and water ad libitum. The animals were divided randomly into 3 groups, five mice in each group, Group 1 (control group) received no treatment, Group 2 received rituximab $1 \mathrm{~m} / \mathrm{kg}$, IP, at days 0,5 , and 10 after wounding, in Group 3, rituximab was topically applied to the wound at days 0 , 5 , and 10 after wounding.

Results: The results yield that the wound healing significantly decreased $(\mathrm{p}<0.05)$ in Groups 2 and 3 as compared to control group. While the results regarding white blood cells (WBCs) count, there is a significant decrease in WBC count in Group 2 ( $p>0.05$ ). Platelets and red blood cell count in significantly increased in Group 3 as compared to control group $(\mathrm{p}<0.05)$. There were no histopathological changes in the skin, kidneys, and spleen. In liver, nonsignificant histopathological changes $(\mathrm{p}>0.05)$ found in Group 2 and 3 as compared to control group.

Conclusion: Rituximab delays wound healing and reduces WBC count in male mice.

Keywords: Rituximab, Wound healing, Lymphocyte, CD20, White blood cells, Mice.

(C) 2017 The Authors. Published by Innovare Academic Sciences Pvt Ltd. This is an open access article under the CC BY license (http://creativecommons. org/licenses/by/4. 0/) DOI: http://dx.doi.org/10.22159/ajpcr.2017.v10i3.15458

\section{INTRODUCTION}

The healing of the wound is a vital process by which the body tissue repairs itself after trauma, in undamaged skin, the epidermis (surface layer) and dermis (deeper layer) form a protective physical barrier against the external environment [1]. This process is divided into many phases: Blood clotting (hemostasis) phase, inflammation phase, tissue growth phase (proliferation), and tissue remodeling phase (maturation), blood clotting may be considered to be part of the inflammation stage instead of a separate stage [2]. Hemostasis (blood clotting): Within the first few minutes after injury, platelets in the blood begin to aggregate at the injured site [3]. Inflammation: During this phase, dead and damaged cells are cleared out, along with bacteria and other pathogens or debris. This takes place through the process of phagocytosis, where white blood cells (WBCs) "engulf" debris. Platelet-derived growth factors are released into the wound that causes the migration and division of cells during the proliferative phase [4]. Proliferation (growth of new tissue): In this phase, angiogenesis, collagen deposition, granulation tissue formation, epithelialization, and wound contraction occur [5]. Maturation (remodeling): During maturation and remodeling, collagen is realigned along tension lines, and cells that are no longer needed are removed by programmed cell death, or apoptosis [6]. The effects of antiinflammatory and immunomodulatory medications on the different stages of the wound healing process can be widespread, and the initial inflammatory may be blunted, or the proliferative and remodeling phases may be abnormal or prolonged [7].

Rituximab is a drug that is licensed for the treatment of relapsed or refractory B-cell lymphoma [8,9] and autoimmune diseases such as rheumatoid arthritis [10]. It lyses B lymphocytes by binding to CD20 antigen found on the surface all B-lymphocyte tumors and activating complement. It is also used with other chemotherapeutic agents to sensitizes resistantcells [11]. It is effective in 40-50\% of B-cell lymphomas when combined with standard chemotherapy [8]. Serum half-life is 59.8 hrs after $1^{\text {st }}$ dose and $17.4 \mathrm{hrs}$ after $4^{\text {th }}$ infusion [11]. Rituximab can be detected in the serum for many months after the dose of the drug [12]. There are different mechanisms to lyses B-cells by rituximab including antibody-dependent cellular cytotoxicity [8], complement dependent cytotoxicity $[8,9]$, and stimulation of apoptotic pathway $[2,9]$. In all cases in which rituximab was given, a rapid decreasing of circulating B-cells occurred [13]. B-cell recovery started at 6-9 months after completion of treatment [2]. Side effects of rituximab include fevers (43\%), chills, nausea, vomiting, orthostatic hypotension $(10 \%)$, and bronchospasm (8\%). Neutropenia and thrombocytopenia may occur [11].

\section{Aims of the study}

The aims of this study were to evaluate the effects of rituximab on the wound healing and the effects on different organs such as liver, spleen, and kidneys in the mice.

\section{METHODS}

Animals

Totally, 15 adult male mice $(25-30 \mathrm{~g})$ were enrolled in this study. Animals were kept in the animal house of College of Medicine/Babylon University, and the temperature was controlled on $25^{\circ} \mathrm{C}$ and $14 \mathrm{hrs} \mathrm{light}$ and $10 \mathrm{hrs}$ dark cycles. The animals were provided with standard diet and water ad libitum.

\section{Incision wound model}

Each mouse was anesthetized by ether. The dorsal skin was shaved then cleaned with $70 \%$ alcohol. A linear dorsal incision $(1 \mathrm{~cm})$ was made 
through the skin. The wound was left uncovered, and the mice housed in individual cages postoperatively. The animals were divided groups, five mice in each randomly into 3 group. Group 1 (control group) received no treatment. Group 2 received rituximab $1 \mathrm{~m} / \mathrm{kg}$, IP, at days 0 , 5, and 10 after wounding. In Group 3, rituximab was topically applied to the wound at days 0,5 , and 10 after wounding.

\section{Blood and histopathological study}

At $15^{\text {th }}$ day, blood samples were taken by direct heart puncture, and the healing tissues were processed for histological study. Liver, spleen, and kidneys were dissected for histopathological study.

\section{Tissues samples preparations}

Liver, spleen, and kidneys were histologically prepared for paraffin section according to Bancroft and Stevens (1987) as follows: Fixation, dehydration, clearing, impregnation, embedding, sectioning, and dewaxing and hydration.

\section{Statistical analysis}

The data are expressed as the mean \pm standard error of mean. The difference among means has been analyzed by one-way ANOVA. The value of $\mathrm{p}<0.05$ was considered as statistically significant.

\section{RESULTS}

Effects of rituximab on the wound healing

The lengths of the wound significantly decreased $(\mathrm{p}<0.05)$ in the control group as compared to Groups 2 and 3 (Tables 1 and 2, Fig. 1, Picture 1). The wound healing, also, significantly decreased $(\mathrm{p}<0.05)$ in Group 2 as compared to Group 3 (Table 3 and Fig. 1).

\section{Hematological effects of rituximab}

WBCs significantly significantly decreased $(\mathrm{p}<0.05)$ in Group 2 as compared with control group, whereas there were no significant differences ( $p>0.05$ ) between control group and Group 3 (Table 4 and Fig. 2). Red blood cells (RBCs) significantly significantly increased $(\mathrm{p}<0.05)$ in Group 3 as compared with control group, whereas there were no significant differences $(p>0.05)$ between control group and Group 2 (Table 5 and Fig. 3). Platelets significantly increased $(\mathrm{p}<0.05)$

Table 1: The means \pm SEM of the wound length of control Group 1 (control group) and Group 2 (received rituximab $1 \mathrm{~m} / \mathrm{kg}$, IP, at days 0,5 , and 10 after wounding)

\begin{tabular}{llll}
\hline Duration & $\begin{array}{l}\text { Means } \pm \text { SEM of } \\
\text { wound length }(\mathbf{m m}) \\
\text { of Group 1 }\end{array}$ & $\begin{array}{l}\text { Means } \pm \text { SEM of } \\
\text { wound length }(\mathbf{m m}) \\
\text { of Group 2 }\end{array}$ & p-value \\
\hline 2 days & $6.8 \pm 1.30384$ & $7.4 \pm 0.89443$ & $>0.05$ \\
4 days & $4.0 \pm 0.44721$ & $5.6 \pm 0.50990$ & $<0.05$ \\
6 days & $0.8 \pm 0.83666$ & $4.6 \pm 0.67823$ & $<0.05$ \\
8 days & $0.0 \pm 0.0$ & $3.4 \pm 0.81240$ & $<0.05$ \\
10 days & $0.0 \pm 0.0$ & $1.2 \pm 0.37417$ & $<0.05$ \\
12 days & $0.0 \pm 0.0$ & $0.0 \pm 0.0$ & $>0.05$ \\
\hline
\end{tabular}

SEM: Standard error of mean

Table 2: The means \pm SEM of the wound length of control Group 1 (control group) and Group 3 (rituximab was topically applied to the wound at days 0,5 , and 10 after wounding)

\begin{tabular}{llll}
\hline Duration & $\begin{array}{l}\text { Means } \pm \text { SEM of } \\
\text { wound length } \mathbf{( m m}) \\
\text { of Group } \mathbf{1}\end{array}$ & $\begin{array}{l}\text { Means } \pm \text { SEM of } \\
\text { wound length } \mathbf{( m m )} \\
\text { of Group 3 }\end{array}$ & p value \\
\hline 2 days & $6.8 \pm 1.30384$ & $6.6 \pm 0.4$ & $>0.05$ \\
4 days & $4.0 \pm 0.44721$ & $5 \pm 0.31623$ & $>0.05$ \\
6 days & $0.8 \pm 0.83666$ & $3 \pm 0.31623$ & $<0.05$ \\
8 days & $0.0 \pm 0.0$ & $1.8 \pm 0.37417$ & $<0.05$ \\
10 days & $0.0 \pm 0.0$ & $0.6 \pm 0.4$ & $>0.05$ \\
12 days & $0.0 \pm 0.0$ & $0.0 \pm 0.0$ & $>0.05$ \\
\hline
\end{tabular}

SEM: Standard error of mean

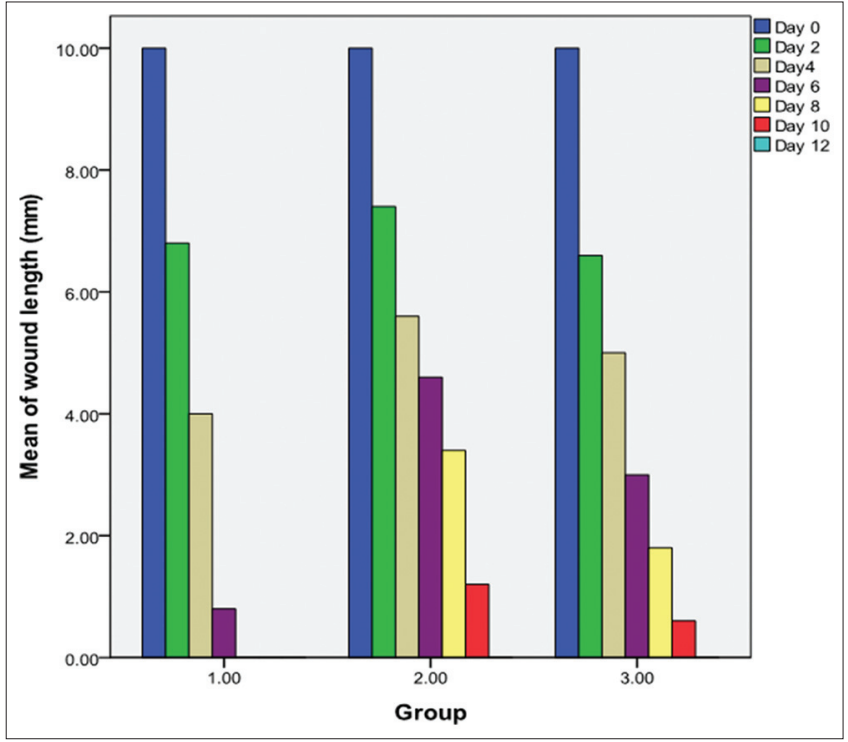

Fig. 1: A comparison of the mean differences of the lengths of the wounds in different groups at different days (Group 1 [control group] received no treatment. Group 2 received rituximab $1 \mathrm{~m} / \mathrm{kg}$ IP, at days 0, 5, and 10 after wounding. In Group 3, rituximab was topically applied to the wound at days 0,5 , and 10 after wounding)

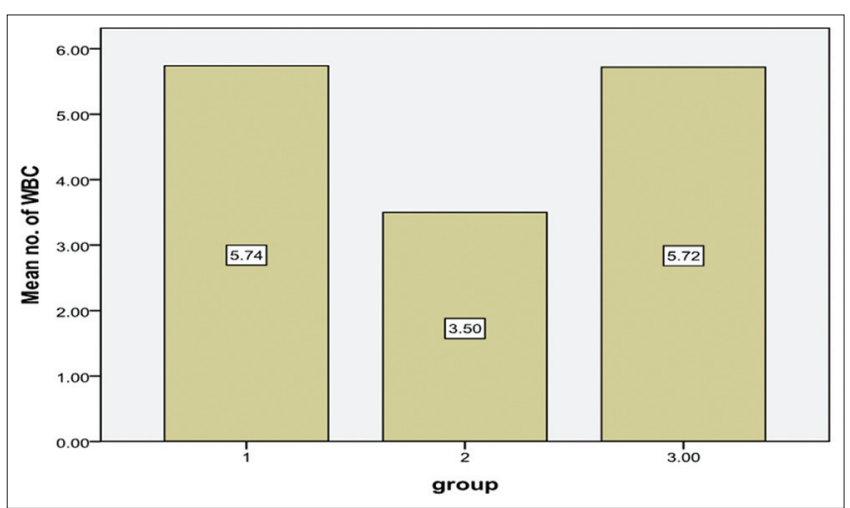

Fig. 2: A comparison of the mean differences of the number of white blood cell between different groups (Group 1 [control group] received no treatment. Group 2 received rituximab $1 \mathrm{~m} / \mathrm{kg}$, IP, at days $\mathbf{0 , 5}$, and 10 after wounding. In Group 3, rituximab was topically applied to the wound at days 0,5 , and 10 after wounding)

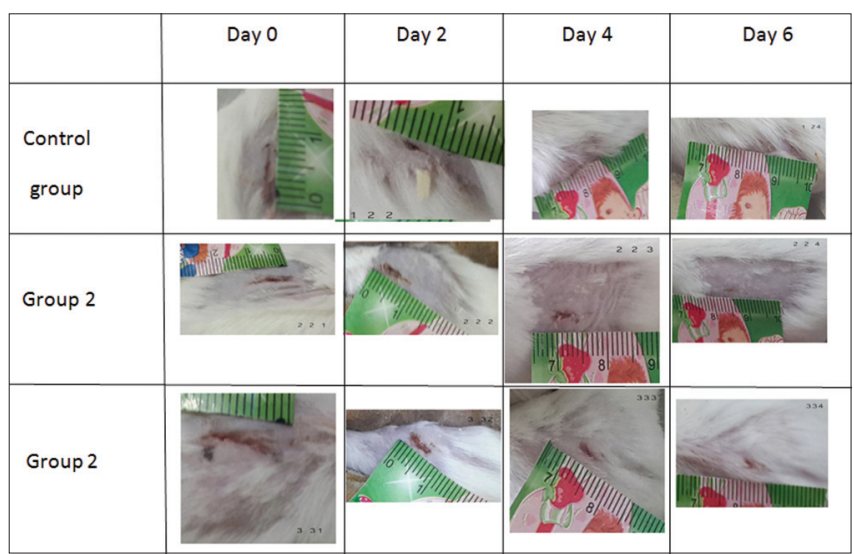

Picture 1: Pictures of wounds in different groups at different days (Group 1 [control group] received no treatment. Group 2 received rituximab $1 \mathrm{~m} / \mathrm{kg}$, IP, at days 0,5 , and 10 after wounding. In Group 3, rituximab was topically applied to the wound at days 0,5 , and 10 after wounding) 
Table 3: The means \pm SEM of the wound length of control Group 2 (received rituximab $1 \mathrm{~m} / \mathrm{kg}$, IP, at days 0,5 , and 10 after wounding) and Group 3 (rituximab was topically applied to the wound at days 0,5 , and 10 after wounding)

\begin{tabular}{llll}
\hline Duration & $\begin{array}{l}\text { Means } \pm \text { SEM of } \\
\text { wound length }(\mathbf{m m}) \\
\text { of Group 2 }\end{array}$ & $\begin{array}{l}\text { Means } \pm \text { SEM of } \\
\text { wound length }(\mathbf{m m}) \\
\text { of Group 3 }\end{array}$ & p value \\
\hline 2 days & $7.4 \pm 0.89443$ & $6.6 \pm 0.4$ & $>0.05$ \\
4 days & $5.6 \pm 0.50990$ & $5 \pm 0.31623$ & $>0.05$ \\
6 days & $4.6 \pm 0.67823$ & $3 \pm 0.31623$ & $<0.05$ \\
8 days & $3.4 \pm 0.81240$ & $1.8 \pm 0.37417$ & $<0.05$ \\
10 days & $1.2 \pm 0.37417$ & $0.6 \pm 0.4$ & $>0.05$ \\
12 days & $0.0 \pm 0.0$ & $0.0 \pm 0.0$ & $>0.05$ \\
\hline
\end{tabular}

Table 4: A comparison of the mean differences of the number of WBC between different groups (Group 1 [control group] received no treatment. Group 2 received rituximab $1 \mathrm{~m} / \mathrm{kg}$, IP, at days 0, 5, and 10 after wounding. In Group 3, rituximab was topically applied to the wound at days 0,5 , and 10 after wounding)

\begin{tabular}{llll}
\hline Duration & Group 1 & Group 2 & Group 3 \\
\hline Group 1 & $\mathrm{X}$ & $2.24^{*}$ & 0.02 \\
Group 2 & $-2.24^{*}$ & $\mathrm{X}$ & $-2.22^{*}$ \\
Group 3 & -0.02 & $2.22^{*}$ & $\mathrm{X}$ \\
\hline
\end{tabular}

*The mean difference is significant $(\mathrm{p}<0.05)$. WBC: White blood cell

Table 5: A comparison of the mean differences of the number of RBC between different groups (Group 1 [control group] received no treatment. Group 2 received rituximab $1 \mathrm{~m} / \mathrm{kg}$, IP, at days 0 , 5 , and 10 after wounding. In Group 3, rituximab was topically applied to the wound at days 0,5 , and 10 after wounding)

\begin{tabular}{llll}
\hline & Group 1 & Group 2 & Group 3 \\
\hline Group 1 & $\mathrm{X}$ & -0.98 & $-1.64^{*}$ \\
Group 2 & 0.98 & $\mathrm{X}$ & -0.66 \\
Group 3 & $1.64^{*}$ & -0.98 & $\mathrm{X}$ \\
\hline
\end{tabular}

*The mean difference is statistically significant $(\mathrm{p}<0.05)$

in Group 3 as compared with control group, whereas there were no significant differences $(p>0.05)$ between control group and Group 2 (Table 6 and Fig. 4). There were no significant differences ( $p>0.05$ ) in the platelet distribution width (PDW) between control group and Groups 2 and 3 (Table 7 and Fig. 5).

\section{Tissue biopsy}

Tissue biopsy from the skin, spleen, kidney, and liver had been underwent for all of the control, intraperitoneally and topically applied rituximab cases and had been studied histopathologically. No changes had been identified in the skin, kidney, spleen and pancreas apart from mild vascular congestion. Histopathological study showed hepatic spotty lytic necrosis of various grades, "focal necroinflammation," recognizable as a small cluster of mononuclear cells (lymphocytes) with or without an adjacent identifiable apoptotic body or bodies (grades fluctuated between 1 and 4) and the highest grades were in the topically applied rituximab cases. However, these histopathological changes in the intraperitoneally and topically applied rituximab cases were being statistically insignificant when analyzed with the control group (Table 8, Fig. 6).

\section{DISCUSSION}

Rituximab is a drug designed as monoclonal, chimeric antibody that targets the CD20 antigen on B-cell, which expressed on normal and
Table 6: A comparison of the mean differences of the number of platelets between different groups [Group 1 [control group] received no treatment. Group 2 received rituximab $1 \mathrm{~m} / \mathrm{kg}$, IP, at days 0, 5, and 10 after wounding. In Group 3, rituximab was topically applied to the wound at days 0,5 , and 10 after wounding)

\begin{tabular}{llll}
\hline & Group 1 & Group 2 & Group 3 \\
\hline Group 1 & $\mathrm{X}$ & -166.6 & $-496^{*}$ \\
Group 2 & 166.6 & $\mathrm{X}$ & -329 \\
Group 3 & $496^{*}$ & 329.4 & $\mathrm{X}$ \\
\hline
\end{tabular}

*The mean difference is statistically significant $(\mathrm{p}<0.05)$

Table 7: A comparison of the mean differences of the number of PDW between different groups (Group 1 [control group] received no treatment. Group 2 received rituximab $1 \mathrm{~m} / \mathrm{kg}$, IP, at days 0,5 , and 10 after wounding. In Group 3, rituximab was topically applied to the wound at days 0,5 , and 10 after wounding)

\begin{tabular}{llll}
\hline & Group 1 & Group 2 & Group 3 \\
\hline Group 1 & $\mathrm{X}$ & -0.24 & -1.16 \\
Group 2 & 0.24 & $\mathrm{X}$ & -0.92 \\
Group 3 & 1.16 & 0.92 & $\mathrm{X}$ \\
\hline
\end{tabular}

*The mean differences is statically significant $(\mathrm{P}<0.05)$.

Table 8: Liver histopathological changes in the all groups (Group 1 [control group] received no treatment. Group 2 received rituximab $1 \mathrm{~m} / \mathrm{kg}$, IP, at days 0,5 , and 10 after wounding. In Group 3, rituximab was topically applied to the wound at days 0,5 , and 10 after wounding)

\begin{tabular}{lllllll}
\hline \multirow{2}{*}{ Group } & \multicolumn{2}{l}{ Grade of spotty lytic necrosis } & \multicolumn{2}{l}{$\begin{array}{l}\text { Total } \\
\text { number }\end{array}$} \\
\cline { 2 - 6 } & Grade & Grade & Grade & Grade & Grade & \\
& $\mathbf{0}$ & $\mathbf{1}$ & $\mathbf{2}$ & $\mathbf{3}$ & $\mathbf{4}$ & \\
\hline 1 & 3 & 0 & 2 & 0 & 0 & 5 \\
2 & 2 & 0 & 3 & 0 & 0 & 5 \\
3 & 2 & 0 & 1 & 1 & 1 & 5 \\
Total & 7 & 0 & 1 & 1 & 1 & 15 \\
number & & & & & & \\
\hline $\mathrm{p}=0.67$ & & & & & &
\end{tabular}

neoplastic B-cells, in addition, it playing a vital role in the treatment of newly diagnosed, and refractory indolent and aggressive CD20 lymphoma, non-Hodgkin lymphoma and chronic lymphocytic leukemia, rituximab has recently used to treat autoimmune diseases such as systemic lupus erythematosus and rheumatoid arthritis [14]

Some studies reported that rituximab is useful in refractory immune thrombocytopenic purpura giving a good response rate, with complete remission and partial remission rate ranging from $48 \%$ to $54 \%[15,16]$. In our research, we have opportunity to test the effect of rituximab in wound healing as a model in animals laboratory as a new approach in rituximab treatment, when we compare the effect of rituximab on total number of WBCs, between the control group (Group 1) and group received rituximab intraperitoneal (Group 2) and group received rituximab locally (Group 3 ). The result showing that there is a significant difference decreasing in total number of WBCs between Group 1 and Group 2 as a result a targeting the CD20 on lymphocytes following rituximab administration, and this result in agreement with other international studies [17]. While comparing between Group 1 and Group 3 in regarding the effect of rituximab on the RBCs count and platelets count, we notice there is a significant difference increasing for both RBCs count, and platelets count. This 


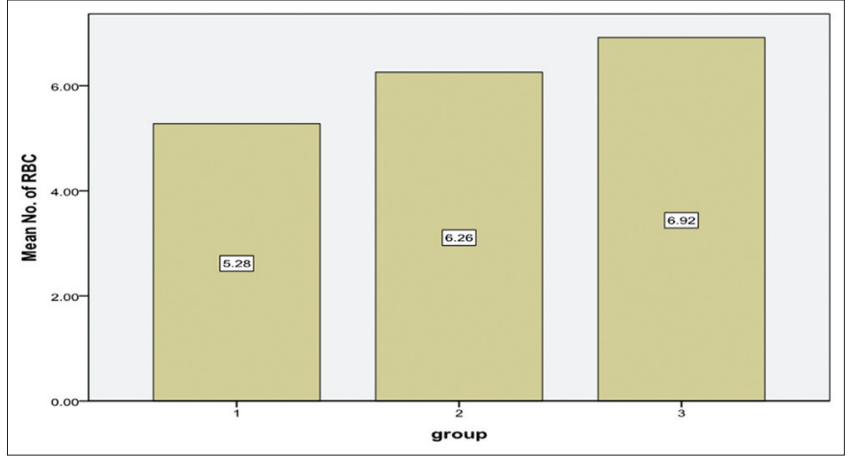

Fig. 3: A comparison of the mean differences of the number of red blood cell between different groups (Group 1 [control group] received no treatment. Group 2 received rituximab $1 \mathrm{~m} / \mathrm{kg}$, IP, at days 0,5 , and 10 after wounding. In Group 3, rituximab was topically applied to the wound at days 0,5 , and 10 after wounding)

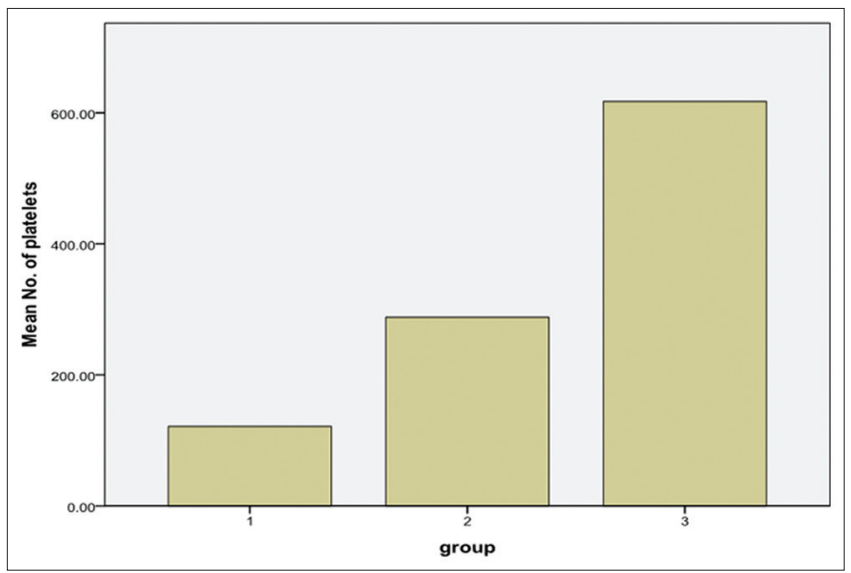

Fig. 4: A comparison of the mean differences of the number of platelets between different groups (Group 1 [control group] received no treatment. Group 2 received rituximab $1 \mathrm{~m} / \mathrm{kg}$, IP, at days $\mathbf{0 , 5}$, and 10 after wounding. In Group 3 , rituximab was topically applied to the wound at days 0,5 , and 10 after wounding)

results may be not related to rituximab effect; however, it is related to the functions of RBCs and platelets in wound injury, the platelets are rapidly diffuse to sites of injury or infection, and potentially modulate inflammatory processes by interacting with leukocytes and by secreting various cytokines, and other inflammatory mediators, also platelets secrete platelet-derived growth factor, in addition, RBCs are able of interact with several types of cells such as macrophages and neutrophills, both of which are involved in the syntheses and regulation of different matrix metalloproteinases in wound healing [18-21]. Compare between Group 1, Group 2, and Group 3 regarding PDW, the result showing no significant difference.

Histopathological changes in the intraperitoneally and topically applied rituximab cases were being statistically insignificant when analyzed with the control group. No previous data had been found about the effect of intraperitoneally and topically applied rituximab on body organs tissue to correlate with, all other studies showed that systemically infused rituximab can cause acute hepatic injury with hepatic spotty lytic necrosis as morphological finding [22-24].

\section{CONCLUSIONS}

Rituximab delays wound healing in male mice, and further researches are needed to study the effects of the drug on wound healing in the human.

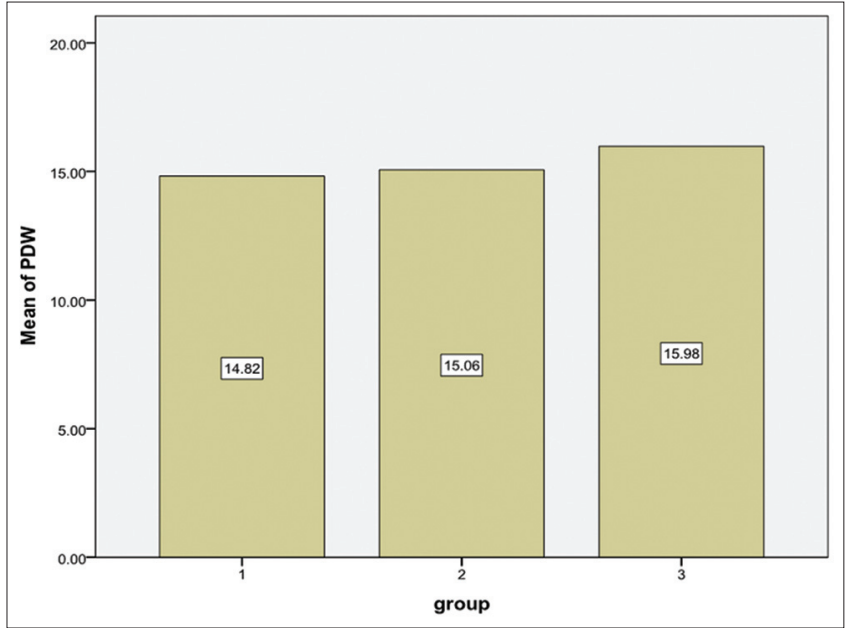

Fig. 5: A comparison of the mean differences of the number of platelet distribution width between different groups (Group 1 [control group] received no treatment. Group 2 received rituximab

$1 \mathrm{~m} / \mathrm{kg}$, IP, at days $\mathbf{0 , 5}$, and 10 after wounding. In Group 3 , rituximab was topically applied to the wound at days 0,5 , and 10 after wounding)

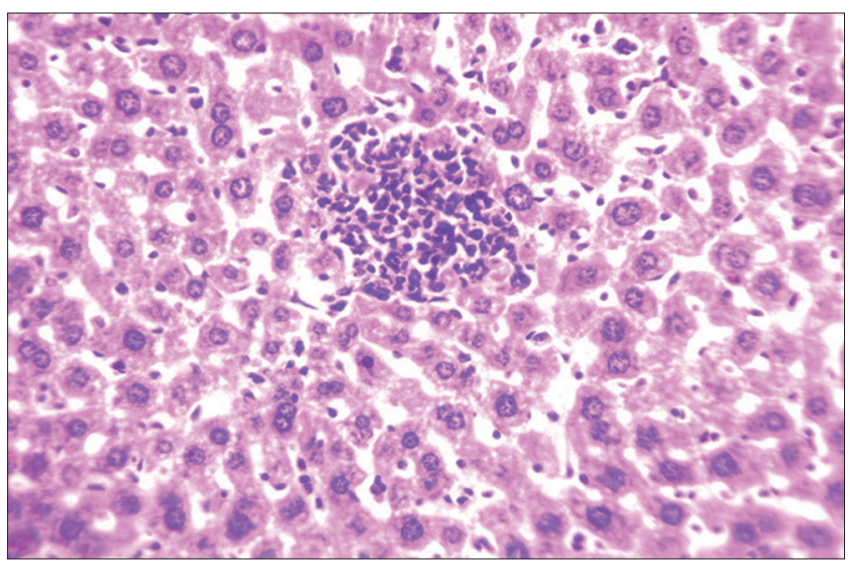

Fig. 6: Photograph of liver from a Group 2. Bland looking hepatocytes with intact architecture, focal chronic inflammatory cells infiltration (lymphocytes) (spotty lytic necrosis) (stained with Hematoxylin and Eosin, with $\times 40$ magnification)

\section{REFERENCES}

1. Rieger S, Zhao H, Martin P, Abe K, Lisse TS. The role of nuclear hormone receptors in cutaneous wound repair. Cell Biochem Funct 2015;33(1):1-13.

2. Stadelmann WK, Digenis AG, Tobin GR. Physiology and healing dynamics of chronic cutaneous wounds. Am J Surg 1998;176 2A Suppl:26S-38.

3. Versteeg HH, Heemskerk JW, Levi M, Reitsma PH. New fundamentals in hemostasis. Physiol Rev 2013;93:327-58.

4. Greenhalgh DG. The role of apoptosis in wound healing. Int J Biochem Cell Biol 1998;30(9):1019-30.

5. Midwood KS, Williams LV, Schwarzbauer JE. Tissue repair and the dynamics of the extracellular matrix. Int $\mathrm{J}$ Biochem Cell Biol 2004;36(6):1031-7.

6. Guo S, Dipietro LA. Factors affecting wound healing. J Dent Res 2010;89(3):219-29.

7. Barnard AR, Regan M, Burke FD, Chung KC, Wilgis EF. Wound healing with medications for rheumatoid arthritis in hand surgery. ISRN Rheumatol 2012;2012:251962.

8. Reff ME, Carner K, Chambers KS, Chinn PC, Leonard JE, Raab R, et al. Depletion of B cells in vivo by a chimeric mouse human monoclonal antibody to CD20. Blood 1994;83(2):435-45. 
9. McLaughlin P, Grillo-López AJ, Link BK, Levy R, Czuczman MS, Williams ME, et al. Rituximab chimeric anti-CD20 monoclonal antibody therapy for relapsed indolent lymphoma: Half of patients respond to a four-dose treatment program. J Clin Oncol 1998;16(8):2825-33.

10. Edwards JC, Leandro MJ, Cambridge G. B lymphocyte depletion therapy with rituximab in rheumatoid arthritis. Rheum Dis Clin North Am 2004;30(2):393-403, viii.

11. Maloney DG, Liles TM, Czerwinski DK, Waldichuk C, Rosenberg J, Grillo-Lopez A, et al. Phase I clinical trial using escalating single-dose infusion of chimeric anti-CD20 monoclonal antibody (IDEC-C2B8) in patients with recurrent B-cell lymphoma. Blood 1994;84(8):2457-66.

12. Vieira CA, Agarwal A, Book BK, Sidner RA, Bearden CM, Gebel HM, et al. Rituximab for reduction of anti-HLA antibodies in patients awaiting renal transplantation: 1. Safety, pharmacodynamics, and pharmacokinetics. Transplantation 2004;77(4):542-8.

13. Genberg $\mathrm{H}$, Hansson A, Wernerson A, Wennberg L, Tydén G. Pharmacodynamics of rituximab in kidney allotransplantation. Am J Transplant 2006;6(10):2418-28.

14. Arroyo-Ávila M, Fred-Jiménez RM, Vilá LM. Early-onset neutropenia induced by rituximab in a patient with lupus nephritis and hemolytic anemia. Case Rep Rheumatol 2015;2015:616787.

15. Weyrich AS, Zimmerman GA. Platelets: Signaling cells in the immune continuum. Trends Immunol 2004;25(9):489-95.
16. Wagner DD, Burger PC. Platelets in inflammation and thrombosis. Arterioscler Thromb Vasc Biol 2003;23:2131-7.

17. Chin-Yee I, Keeney M, Krueger L, Dietz G, Moses G. Supernatant from stored red cells activates neutrophils. Transfus Med 1998;8(1):49-56.

18. Singer AJ, Clark RA. Cutaneous wound healing. N Engl J Med 1999;341(10):738-46.

19. DeLeve L, Kaplowitz N, editors. Drug-Induced Liver Disease. $3^{\text {rd }}$ ed. Waltham, MA: Academic Press; 2013. p. 776

20. Qazilbash MH, Qu Z, Hosing C, Couriel D, Donato M, Giralt S, et al. Rituximab-induced acute liver failure after an allogeneic transplantation for chronic myeloid leukemia. Am J Hematol 2005;80(1):43-5.

21. Burak KW, Swain MG, Santodomingo-Garzon T, Lee SS, Urbanski SJ, Aspinall AI, et al. Rituximab for the treatment of patients with autoimmune hepatitis who are refractory or intolerant to standard therapy. Can J Gastroenterol 2013;27(5):273-80.

22. Dunleavy K, Tay K, Wilson WH. Rituximab-associated neutropenia. Semin Hematol 2010;47(2):180-6.

23. Garcia-Chavez J, Majluf-Cruz A, Montiel-Cervantes L, Esparza MG, Vela-Ojeda J. Rituximab therapy for chronic and refractory immune thrombocytopenic purpura: A long-term follow-up analysis. Ann Hematol 2007;86(12):871-7.

24. Stasi R, Pagano A, Stipa E, Amadori S. Rituximab chimeric anti-CD20 monoclonal antibody treatment for adults with chronic idiopathic thrombocytopenic purpura. Blood 2001;98(4):952-7. 